\title{
Snack bars enriched with Spirulina for schoolchildren nutrition
}

\author{
Bárbara Franco LUCAS ${ }^{1}$, Ana Priscila Centeno da ROSA ${ }^{1}$, Lisiane Fernandes de CARVALHO ${ }^{1}$, \\ Michele Greque de MORAIS ${ }^{2}$, Thaisa Duarte SANTOS ${ }^{1}$, Jorge Alberto Vieira COSTA ${ }^{1 *}$
}

\begin{abstract}
The aim of this study was to develop snack bars nutritionally enriched with Spirulina and evaluate if there was acceptance of the sensorial attributes by schoolchildren. Snack bars enriched with Spirulina (2\% and 6\%) and a control formulation ( $0 \%$ Spirulina) were prepared. The samples were evaluated regarding nutritional content, microstructure, and sensorial characteristics. Furthermore, the study of stability during storage (30 days) was carried out. The addition of $2 \%$ and $6 \%$ of Spirulina provided a protein increase of $11.7 \%$ and $29.9 \%$, respectively. The physicochemical and microbiological parameters remained stable during the storage of 30 days. Sensory evaluation showed that snack bars enriched with 6\% Spirulina presented no significant difference $(\mathrm{p}>0.05)$ compared to the control samples. We concluded that Spirulina can be used as a nutritive ingredient in snack bars designed for infant feeding without sensorial characteristics change.
\end{abstract}

Keywords: cereal bars; microalga; ready-to-eat food; sensory evaluation; stability during storage.

Practical Application: Spirulina addition in snack bars results in protein increase without affecting sensorial quality.

\section{Introduction}

Diets with low concentrations of nutrients such as protein and minerals contribute to the increase of diseases (Müller \& Krawinkel, 2005; World Health Organization, 2014), besides affecting the growth and development of children (United Nations Children's Fund, 2018). In 2014, during the Second International Conference on Nutrition, over 170 countries adopted the political Declaration to ensure that all people have access to more healthy and sustainable diets. Such countries should achieve concrete results by 2025 through firm policies and actions (World Health Organization, 2014). In this context, the microalga Spirulina, which has a high concentration of nutrients and biocompounds (Batista et al., 2017; Rodríguez De Marco et al., 2014), has been used to improve the nutritional health of the population.

The Food and Drug Administration (FDA) approved Spirulina as safe food without toxicological effects on human health and provide GRAS (Generally Recognized as Safe) certification (Food and Drug Administration, 2002a). The compounds present in Spirulina biomass can exhibit antiviral, antibacterial, anticancer, antioxidant and anti-inflammatory roles which could be useful in the treatment of diseases (Hosseini et al., 2013). Foods such as pasta (Rodríguez De Marco et al., 2014), cookies (Batista et al., 2017; Morais et al., 2006), and ready-to-eat (RTE) extruded snacks (Lucas et al., 2017) have already been enriched with Spirulina.

Snack bars are also considered ready-to-eat food and are increasingly present in the diet of children. These foods attract the consumers due to their versatility and convenience (Ramírez-Jiménez et al., 2018), besides the high sensorial quality (Aigster et al., 2011; Bialek et al., 2016; Prazeres et al., 2017). In this context, studies have been carried out aiming for the introduction of bioactive compounds into formulations of snack bars in order to provide healthier food for the consumers (Pinto et al., 2017).

Several studies have reported the influence of functional ingredients such as bean flour (Ramírez-Jiménez et al., 2018), lentils (Ryland et al., 2010) and fruit pulp (Prazeres et al., 2017) in the nutritional enrichment of snack bars. However, there are only a limited number of studies that evaluate the influence of Spirulina in the characteristics of this food.

Furthermore, several works that evaluated the sensory acceptance of foods enriched with Spirulina are found in the literature (Batista et al., 2017; Lucas et al., 2018; Santos et al., 2016), however, there are no studies which evaluated the sensory acceptance among children. Therefore, the aim of this study was to develop snack bars nutritionally enriched with Spirulina and evaluate if there was acceptance of the sensorial attributes by schoolchildren.

\section{Material and methods}

\subsection{Materials}

The ingredients used for the development of the snack bars were: Spirulina sp. LEB 18 biomass, oat flakes, rice flakes, brown sugar, glucose syrup, water, vegetable fat, lecithin and maltodextrin. The microalga Spirulina sp. LEB 18, was isolated from Mangueira Lagoon (Morais et al., 2008) and their biomass produced at the Pilot Plant of the Laboratory of Biochemical Engineering located in Rio Grande do Sul, Brazil (33³0'13"S 530.'59”W). The biomass was collected, dried and ground to a fine powder

${ }^{1}$ Laboratório de Engenharia Bioquímica, Escola de Química e Alimentos, Universidade Federal do Rio Grande - FURG, Rio Grande, RS, Brasil

${ }^{2}$ Laboratório de Microbiologia e Bioquímica, Escola de Química e Alimentos, Universidade Federal do Rio Grande - FURG, Rio Grande, RS, Brasil

${ }^{*}$ Corresponding author: jorgealbertovc@terra.com.br 
in a ball mill (Model Q298, Quimis, Brazil). Afterwards, the biomass was sieved through a 48 mesh $(0.3 \mathrm{~mm})$ and stored in metallized bags at $4{ }^{\circ} \mathrm{C}$. The other ingredients were purchased in a local market.

\subsection{Preparation of snack bars}

Three formulations were developed: C (Control), SP2 and SP6 (Table 1). Samples SP2 and SP6 were prepared by addition of $2 \%$ and $6 \%$ Spirulina sp. LEB 18, respectively, replacing the same amount of oat flakes in the control formulation.

Firstly, the oat and rice flakes were weighed and mixed. Afterward, the other ingredients were heated under constant mixing in a stainless-steel pan until form the agglutination syrup $\left(79^{\circ} \mathrm{Brix}\right)$. Then, this syrup was added and homogenized with the cereals pre-mixed. After, the resultant mixture was molded on portions of $35 \mathrm{~g}$ into a rectangular aluminum tray to obtain a snack bar with dimensions of $112 \mathrm{~mm} \times 43 \mathrm{~mm} \times 13 \mathrm{~mm}$ and then baked in an oven at $130^{\circ} \mathrm{C}$, during $15 \mathrm{~min}$ (Sun-Waterhouse et al., 2010). Afterward, the samples were cooled at room temperature and stored $\left(25 \pm 2{ }^{\circ} \mathrm{C}\right)$ in metalized bags of polyethylene (internal layer) and polyester (external layer) under vacuum for further analyses.

\subsection{Analyses of snack bars}

\section{Proximate composition}

The Association of Official Analytical Chemists (AOAC) procedures were used to determine the proximate composition of the snack bars. Protein quantification was performed according to micro-Kjeldahl method ( $\left.n^{\circ} .960 .52\right)$, with conversion factor of 6.25. Lipids, ash and moisture were quantified according to methods 920.39, 923.03 and 925.10, respectively (Association of Official Analytical Chemists, 1995). Carbohydrates were calculated by difference.

Color

The color of the snack bars was measured instrumentally using a colorimeter (Chroma meter CR-400, Konica Minolta, Tokyo, Japan). The results were expressed as $L^{*}$ (black $=0$ and white $\left.=100\right)$, $\mathrm{a}^{*}($ green $=-60$ and red $=+60)$ and $\mathrm{b}^{*}($ blue $=-60$ and yellow $=+60)$.

Total color difference $(\Delta \mathrm{E})$ between the samples with and without Spirulina was calculated according to Equation 1, where, $\mathrm{L}_{0}^{*}, \mathrm{a}_{0}^{*}$, and $\mathrm{b}_{0}^{*}$ were the values obtained in the control sample

Table 1. Formulations of snack bar control (C) and snack bars with $2 \%$ of Spirulina (SP2) and 6\% of Spirulina (SP6).

\begin{tabular}{lrrr}
\hline \multicolumn{1}{c}{ Ingredients $(\mathrm{g} / 100 \mathrm{~g})$} & $\mathrm{C}$ & SP2 & SP6 \\
\hline Oat flakes & 35.3 & 33.3 & 29.3 \\
Rice flakes & 15.8 & 15.8 & 15.8 \\
Brown sugar & 13.2 & 13.2 & 13.2 \\
Glucose syrup & 16.0 & 16.0 & 16.0 \\
Water & 9.2 & 9.2 & 9.2 \\
Vegetable fat & 1.5 & 1.5 & 1.5 \\
Lecithin & 2.0 & 2.0 & 2.0 \\
Maltodextrin & 7.0 & 7.0 & 7.0 \\
Spirulina powder & 0.0 & 2.0 & 6.0 \\
\hline
\end{tabular}

(without Spirulina). Chroma $C^{\star}$ (saturation) and hue angle $\left(\mathrm{h}^{\circ}\right)$ were determined following Equations 2 and 3, respectively (Konica Minolta, 2007).

$$
\begin{aligned}
& \Delta \mathrm{E}=\sqrt{\left(\mathrm{L}^{*}-\mathrm{L}_{0}^{*}\right)^{2}+\left(\mathrm{a}^{*}-\mathrm{a}_{0}^{*}\right)^{2}+\left(\mathrm{b}^{*}-\mathrm{b}_{0}^{*}\right)^{2}} \\
& \mathrm{C}^{*}=\left(\mathrm{a}^{* 2}+\mathrm{b}^{* 2}\right)^{1 / 2} \\
& \mathrm{~h}^{\mathrm{o}}=\tan ^{-1}\left(\frac{\mathrm{b}^{*}}{\mathrm{a}^{*}}\right)
\end{aligned}
$$

\section{Texture}

The texture of the snack bars was measured with a texture analyzer TA-XTplus (Stable Microsystems, Surrey, UK) equipped with a $25 \mathrm{~kg}$ load cell, using a cutting test at a speed of $2 \mathrm{~mm} / \mathrm{s}$ and distance of the sample of $10 \mathrm{~mm}$. The hardness was calculated as the maximum force required $(\mathrm{N})$ for the probe to penetrate $50 \%$ of the snack bars thickness.

\section{Microstructure}

Samples were cut to a thickness of $5 \mathrm{~mm}$ and placed in double-sided adhesive tape mounted on aluminum stub. The microstructures were observed in a scanning electron microscope (JSM-6610LV, JEOL Ltd., Japan) using low vacuum and $15 \mathrm{kV}$ accelerating voltage.

\section{Microbiological evaluation}

The snack bars were analyzed microbiologically following the methods described by Bacteriological Analytical Manual (BAM) (Food and Drug Administration, 2002b, 2007). The analyses performed were coliforms at $45^{\circ} \mathrm{C}$ and Salmonella (Lucas et al., 2018).

\section{Stability during storage}

The fresh snack bars were stored in metalized bags (polyethylene: internal layer and polyester: external layer) under vacuum and maintained at room temperature $\left(25 \pm 2{ }^{\circ} \mathrm{C}\right)$. The properties of color, texture, moisture and microbiological attributes (coliforms at $45{ }^{\circ} \mathrm{C}$ and Salmonella) were analyzed after 15 and 30 days of storage, according to the procedures described previously.

\section{Sensory properties}

The sensory evaluation was performed with fifty children aged between 8 and 13, students of the Center for Comprehensive Care for Children and Adolescents (CAIC) (Rio Grande, Brazil), after obtained the consent from children's parents and the head teacher. Children evaluated the freshly prepared snack bars in terms of their attributes (appearance, flavor, and taste). The analysis was performed using a 5-point facial scale with verbal anchors $(1=$ dislike a lot, $2=$ dislike, $3=$ neither like nor dislike, 4 = like, $5=$ like a lot). The sensory analysis was approved by the Research Ethics Committee of the Federal University of Rio Grande (approval no 49/2016, Process 23116.002572/2016-05). 


\section{Statistical analysis}

Data were analyzed using analysis of variance (ANOVA) and the Tukey test was used to determine the differences between the means at 95\% ( $<$ 0.05) (Montgomery, 2009).

\section{Results and discussion}

\subsection{Proximate composition of freshly prepared snack bars}

The proximate composition showed that snack bars enriched with Spirulina presented protein content significantly higher $(\mathrm{p}<0.05)$ than the control formulation (Table 2$)$. The nutritional increase obtained after the addition of $2 \%$ and $6 \%$ of microalga was $11.7 \%$ and $29.9 \%$ in protein content, respectively. This occurs due to the high protein concentration (59.5\%) of Spirulina sp. LEB 18 biomass used in the present study (Lucas et al., 2017).

Several studies have used Spirulina as an ingredient for nutritional enrichment of food. Batista et al. (2017) developed cookies with $2 \%$ and $6 \%$ of Spirulina biomass and observed increases of $24 \%$ and $59 \%$ in protein content, respectively, when compared to the control cookie (0\% Spirulina). Lucas et al. (2018) prepared snacks enriched with Spirulina sp. LEB 18 and reported a nutritional increase of protein content $(22.6 \%)$. Furthermore, the authors revealed that the concentration of carotenoids increased from $1.57 \pm 0.02 \mu \mathrm{g} / \mathrm{g}$ in the control formulation to $14.68 \pm 0.03 \mu \mathrm{g} / \mathrm{g}$ in the formulation with Spirulina, without showing significant modifications on the physical parameters of the snacks as expansion index and hardness. Rodríguez De Marco et al. (2014) added Spirulina biomass in pasta and observed an improvement in protein concentration. In this work, authors obtained $23.74 \%$ of protein content for the cooked pasta prepared with $20 \%$ of Spirulina addition, while the control formulation (without microalgae) showed a protein concentration of $13.09 \%$. Furthermore, the authors verified that there were no biological activity losses during the cooking process.

The replacement of oat flakes by Spirulina biomass did not influence lipid concentration $(p>0.05)$ due to the similarity between the lipid composition of oat flakes (Núcleo de Estudos e Pesquisas em Alimentação, 2011) and Spirulina biomass (Lucas et al., 2017). Regarding ash content, the addition of $2 \%$ and $6 \%$ of Spirulina resulted in a significant increase $(\mathrm{p}<0.05)$ of that component, indicating an increase in mineral concentration. This is relevant from a nutritional aspect, as according to Henrikson (2009), among the minerals contained within the biomass of this microalgae are calcium, iron, and magnesium. These micronutrients are essential for the health and the development of children (United Nations Children's Fund, 2018).
Similar behavior was observed by Santos et al. (2016), who elaborated shake for the elderly enriched with Spirulina sp. LEB 18 biomass and obtained an increase in mineral content when compared to the control sample. The shake with Spirulina presented $3.48 \%$ of ash, a result significantly greater $(\mathrm{p}<0.05)$ than in the shake without microalga (3.14\%). In another study, researchers developed food supplement for athletes added with biomass of Spirulina sp. LEB 18 and observed an increase in mineral content. The authors obtained $3.65 \%$ of ash content in the electrolyte replenisher without the microalga, while in the product added with Spirulina sp. LEB 18, this content was 4.00\% (Carvalho et al., 2017).

Moisture content is a relevant indicator of food shelf life (Oyeyinka et al., 2018). The high moisture content is directly related to food degradation and microbial growth (Mathlouthi, 2001). In the present study, snack bars presented moisture content according to the value established by FDA (Food and Drug Administration) for cereal flours and related products (<15\%) (Food and Drug Administration, 2017). The same trend was observed by Gutkoski et al. (2007) who developed oat based snack bars and obtained moisture content ranging from 10.75 to $13.95 \%$ and also by Srebernich et al. (2016) who reported moisture content ranging from 13.36 to $13.50 \%$ in snack bars developed from rice and oat flakes added with acacia gum, inulin, and sorbitol.

\subsection{Color characteristics of freshly prepared and stored snack bars}

The snack bars with Spirulina biomass presented an appearance similar to the control, but with the green color from the microalga (Figure 1). Table 3 presented the color parameters of the snack bars. The addition of 2 and $6 \%$ Spirulina significantly affected $(p<0.05)$ the color parameters of the snack bars when compared to the control formulation. These results should be related to the presence of pigments from Spirulina, such as chlorophylls, carotenoids and phycocyanin (Barkallah et al., 2017; Lucas et al., 2018).

The addition of this microalga in the formulation led to lower values of $\mathrm{L}^{\star}, \mathrm{a}^{\star}, \mathrm{b}^{\star}$, and $\mathrm{C}^{\star}$ parameters as well as to an increase of hue angle. The results showed that the sample enriched with $6 \%$ of Spirulina presented a more intense green color when compared to samples C and SP2. According to Fradique et al. (2010), this makes microalgae a sustainable alternative as coloring agents with nutritional relevance (Table 2 ) over synthetic coloring agents.

Regarding the hue angle, the enrichment with Spirulina resulted in values between yellow $\left(90^{\circ}\right)$ and green $\left(180^{\circ}\right)$, which

Table 2. Proximate composition of snack bar control (C) and snack bars with 2\% of Spirulina (SP2) and 6\% of Spirulina (SP6).

\begin{tabular}{|c|c|c|c|}
\hline Parameters & $\mathrm{C}$ & SP2 & SP6 \\
\hline Protein (g/100 g dry basis) & $9.31^{\mathrm{c}} \pm 0.13$ & $10.40^{\mathrm{b}} \pm 0.03$ & $12.09^{a} \pm 0.05$ \\
\hline Lipids (g/100 g dry basis) & $6.12^{\mathrm{a}} \pm 0.09$ & $6.02^{\mathrm{a}} \pm 0.12$ & $6.16^{\mathrm{a}} \pm 0.13$ \\
\hline Ash (g/100 g dry basis) & $1.24^{\mathrm{c}} \pm 0.01$ & $1.46^{\mathrm{b}} \pm 0.02$ & $2.00^{\mathrm{a}} \pm 0.03$ \\
\hline Moisture (g/100 g) & $10.73^{\mathrm{b}} \pm 0.38$ & $10.75^{\mathrm{b}} \pm 0.10$ & $12.68^{\mathrm{a}} \pm 0.66$ \\
\hline Carbohydrates (g/100 g) & 72.60 & 71.37 & 67.07 \\
\hline
\end{tabular}

Mean \pm standard deviation $(n=3)$. Different letters in the same line mean significant differences between samples $(\mathrm{p}<0.05)$. 

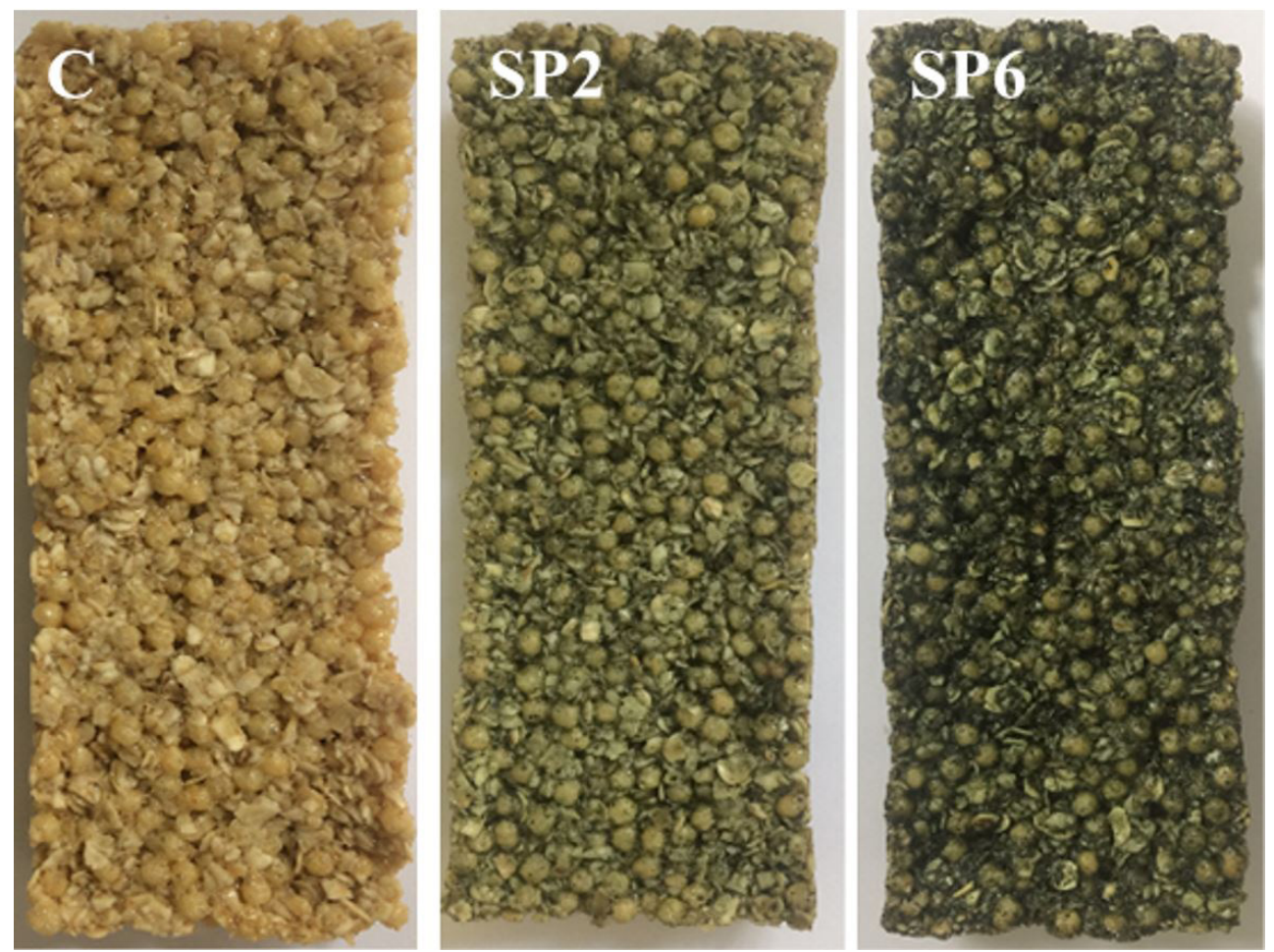

Figure 1. Snack bar control (C) and snack bars with 2\% of Spirulina (SP2) and 6\% of Spirulina (SP6).

Table 3. Color parameters of snack bar control (C) and snack bars with $2 \%$ of Spirulina (SP2) and 6\% of Spirulina (SP6).

\begin{tabular}{|c|c|c|c|c|c|c|}
\hline Storage & $\mathrm{L}^{*}$ & $a^{*}$ & $\mathrm{~b}^{*}$ & $\mathrm{C}^{*}$ & $\mathrm{~h}$ & $\Delta \mathrm{E}$ \\
\hline \multicolumn{7}{|l|}{0 days } \\
\hline $\mathrm{C}$ & $50.37^{a} \pm 0.28$ & $5.10^{\mathrm{a}} \pm 0.05$ & $24.30^{\mathrm{a}} \pm 0.13$ & $24.83^{\mathrm{a}} \pm 0.12$ & $78.14^{c} \pm 0.17$ & * \\
\hline SP2 & $34.04^{b} \pm 0.66$ & $-1.34^{\mathrm{b}} \pm 0.01$ & $14.76^{\mathrm{b}} \pm 0.19$ & $14.82^{\mathrm{b}} \pm 0.19$ & $95.17^{\mathrm{b}} \pm 0.02$ & $19.98^{b} \pm 0.49$ \\
\hline SP6 & $27.41^{c} \pm 1.00$ & $-2.05^{c} \pm 0.05$ & $9.79^{c} \pm 0.20$ & $10.00^{c} \pm 0.21$ & $101.81^{\mathrm{a}} \pm 0.21$ & $28.09^{\mathrm{a}} \pm 0.74$ \\
\hline \multicolumn{7}{|l|}{15 days } \\
\hline $\mathrm{C}$ & $50.25^{a} \pm 0.31$ & $5.07^{\mathrm{a}} \pm 0.03$ & $24.48^{a} \pm 0.23$ & $25.00^{\mathrm{a}} \pm 0.23$ & $78.30^{c} \pm 0.09$ & * \\
\hline SP2 & $34.30^{\mathrm{b}} \pm 0.87$ & $-1.36^{b} \pm 0.03$ & $14.25^{\mathrm{b}} \pm 0.13$ & $14.32^{\mathrm{b}} \pm 0.13$ & $95.44^{b} \pm 0.10$ & $20.01^{\mathrm{b}} \pm 0.74$ \\
\hline SP6 & $27.59^{c} \pm 0.66$ & $-2.06^{c} \pm 0.07$ & $9.50^{c} \pm 0.20$ & $9.72^{c} \pm 0.19$ & $102.24^{\mathrm{a}} \pm 0.56$ & $28.09^{\mathrm{a}} \pm 0.63$ \\
\hline \multicolumn{7}{|l|}{30 days } \\
\hline $\mathrm{C}$ & $50.45^{\mathrm{a}} \pm 0.44$ & $5.11^{\mathrm{a}} \pm 0.19$ & $24.38^{a} \pm 0.16$ & $24.91^{\mathrm{a}} \pm 0.20$ & $78.15^{c} \pm 0.37$ & * \\
\hline SP2 & $33.84^{b} \pm 0.91$ & $-1.35^{\mathrm{b}} \pm 0.08$ & $14.37^{\mathrm{b}} \pm 0.26$ & $14.43^{\mathrm{b}} \pm 0.26$ & $95.37^{b} \pm 0.28$ & $20.44^{\mathrm{b}} \pm 0.86$ \\
\hline SP6 & $27.35^{c} \pm 0.85$ & $-2.03^{c} \pm 0.13$ & $9.63^{c} \pm 0.44$ & $9.84^{c} \pm 0.40$ & $101.96^{a} \pm 1.26$ & $28.33^{\mathrm{a}} \pm 0.80$ \\
\hline
\end{tabular}

$-\mathrm{b}^{*}$ : blueness; $\mathrm{C}^{*}$ : Chroma; h: hue angle; $\Delta \mathrm{E}$ : Total color difference; $\left(^{*}\right)$ : Standard values $\left(\mathrm{L}^{*}{ }_{0}, \mathrm{a}_{0}^{*}\right.$; $\left.\mathrm{b}^{*}{ }_{0}\right)$ used in the calculation of $\Delta \mathrm{E}$ of SP2 and SP6.

could be due to the pigments present in the raw material, such as carotenoids and chlorophylls. The total color variation was directly related to the concentration of Spirulina added, being higher after larger microalga increments. Results of $\Delta \mathrm{E}$ superior to 12 indicate that the colors of the samples are perceptible and different from the control (Limbo \& Piergiovanni, 2006; You et al., 2018).

Lucas et al. (2018) also obtained a decrease in color parameters $\left(\mathrm{L}^{*}, \mathrm{~b}^{*}\right.$ and, $\left.\mathrm{C}^{*}\right)$ after addition of $2.6 \%$ Spirulina in the extruded snacks formulation as well as a total color difference $(\Delta \mathrm{E})$ of 30.50. Barkallah et al. (2017) developed yogurt and observed a reduction in $\mathrm{L}^{*}, \mathrm{a}^{*}$, and $\mathrm{b}^{*}$ parameters after addition of Spirulina.
Silva Figueira et al. (2011) prepared gluten-free bread enriched with Spirulina microalga and verified a reduction of $L^{*}$ from 75.15 (control sample) to 28.83 (sample with 5\% Spirulina).

Concerning the storage of 15 and 30 days, no significant changes $(p>0.05)$ were observed on colors parameters $\left(L^{*}, a^{*}, b^{*}, C^{*}\right.$, hue, and $\left.\Delta E\right)$, demonstrating the color stability of all the formulations (C, SP2, and SP6) along 30 days. Similar to our results, Barkallah et al. (2017) revealed that there was no significant change in $\mathrm{a}^{*}$ and $\mathrm{b}^{*}$ parameters of Spirulina-fortified yogurts during 28 days of storage. Thus, we can point out that the color obtained from Spirulina could remain stable during the storage of different food. 


\subsection{Physicochemical characteristics of freshly prepared and stored snack bars}

Hardness is an important physical characteristic to be evaluated and is directly related with the food sensory acceptance. In the present study, the formulations C, SP2, and SP6 did not show changes in hardness or in moisture content during the storage of 30 days $(p>0.05)$. Furthermore, there was no significant difference $(\mathrm{p}>0.05)$ between SP2 and C (Table 4), indicating that addition of $2 \%$ Spirulina does not alter the hardness and concentration of moisture of the snack bars. Batista et al. (2017) observed similar behavior in cookies enriched with microalgae. In the study, authors revealed that the addition of $2 \%$ microalgal biomass did not cause structural changes enough to modify the hardness of the cookies.

The moisture content of the SP6 sample was statistically higher $(\mathrm{p}<0.05)$ than the content observed in samples C and SP2. The result obtained for SP6 may be due to the substitution of higher concentration of oats flakes which contains approximately 9\% of moisture (Núcleo de Estudos e Pesquisas em Alimentação, 2011) by Spirulina biomass with $15.8 \%$ of moisture (Unpublished data). Moreover, the moisture content in the sample SP6 (Table 4) may also have influenced directly the texture.

Table 4. Physical properties of snack bar control (C) and snack bars with $2 \%$ of Spirulina (SP2) and 6\% of Spirulina (SP6).

\begin{tabular}{lcc}
\hline \multicolumn{1}{c}{ Storage } & Hardness $(\mathrm{N})$ & Moisture $(\mathrm{g} / 100 \mathrm{~g})$ \\
\hline 0 days & & \\
C & $81.35^{\mathrm{a}} \pm 3.74$ & $10.73^{\mathrm{b}} \pm 0.38$ \\
SP2 & $82.45^{\mathrm{a}} \pm 5.42$ & $10.75^{\mathrm{b}} \pm 0.10$ \\
SP6 & $52.36^{\mathrm{b}} \pm 3.37$ & $12.68^{\mathrm{a}} \pm 0.66$ \\
15 days & & \\
C & $83.17^{\mathrm{a}} \pm 4.20$ & $10.85^{\mathrm{b}} \pm 0.12$ \\
SP2 & $84.14^{\mathrm{a}} \pm 4.85$ & $10.97^{\mathrm{b}} \pm 0.53$ \\
SP6 & $52.97^{\mathrm{b}} \pm 1.75$ & $12.87^{\mathrm{a}} \pm 0.23$ \\
30 days & & \\
C & $86.76^{\mathrm{a}} \pm 5.83$ & $10.61^{\mathrm{b}} \pm 0.30$ \\
SP2 & $89.37^{\mathrm{a}} \pm 5.74$ & $10.81^{\mathrm{b}} \pm 0.41$ \\
SP6 & $56.91^{\mathrm{b}} \pm 0.98$ & $12.18^{\mathrm{a}} \pm 0.24$ \\
\hline
\end{tabular}

Means \pm standard deviation $(n=3)$. Different letters in the same column mean significant differences between samples $(\mathrm{p}<0.05)$.
The SP6 $(0,15$, and $30 \mathrm{~d})$ showed hardness significantly lower $(\mathrm{p}<0.05)$ than the observed in samples C and SP2 (Table 4). The micrographs (Figure 2) confirm that the SP6 sample presented a less compact structure when compared to C and SP2 structures. Despite that, the values obtained for all the samples are in agreement with previous studies that developed snack bars. Similar results were observed by Sun-Waterhouse et al. (2010) and by Prazeres et al. (2017) in snack bars added with fruit.

\subsection{Microbiological characteristics of freshly prepared and stored snack bars}

The results of the microbiological analyses $\left(<3 \mathrm{MPN} \mathrm{g}^{-1}\right.$ for coliforms at $45^{\circ} \mathrm{C}$ and absence in $25 \mathrm{~g}$ of Salmonella) indicated that the snack bars were processed under adequate hygienic sanitary conditions and therefore were considered suitable for consumption. Furthermore, the results confirm that the samples C, SP2, and SP6 were packaged and stored properly without risk of microbial contamination (by coliforms at $45^{\circ} \mathrm{C}$ or Salmonella) during the storage of 30 days.

\subsection{Sensory evaluation of freshly prepared snack bars}

The sensory attributes are the factors that most influence the consumer preference (Pinto et al., 2017). According to Potter et al. (2013), children above 8 years are able to express the degree of liking of the sensory attributes using a 5-point facial scale with verbal anchors. The samples C and SP6 had no significant differences $(\mathrm{p}>0.05)$ regarding the appearance, which demonstrates that the children visually accepted the addition of higher concentrations of Spirulina (6\%) (Figure 3). This was probably due to the color of the SP6 sample remained greener (Table 3) than the SP2 sample, being more attractive for schoolchildren. Thus, Spirulina can be used as a coloring agent and additionally increase the nutritional content (Table 2) of snack bars.

Studies have already reported the high sensory acceptance of food enriched with Spirulina by the consumers. Santos et al. (2016) elaborated a shake for the elderly added with Spirulina sp. LEB 18 and verified higher sensory acceptance scores (7.68) when compared to the commercial shake (6.89). Lucas et al. (2018) reported that extruded snacks enriched with Spirulina sp. LEB 18 had a high acceptance rate (82\%). In such study, the authors had average scores for flavor, texture, taste and overall acceptance between "like moderately" and "like very much". Batista et al.
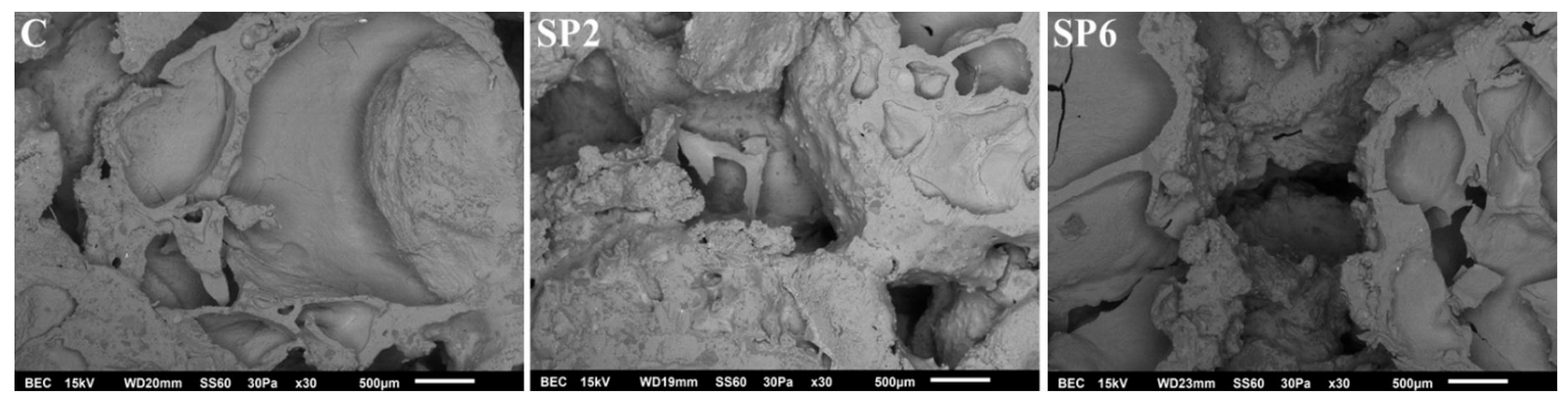

Figure 2. Microstructure of snack bar control (C) and snack bars with 2\% of Spirulina (SP2) and 6\% of Spirulina (SP6). 


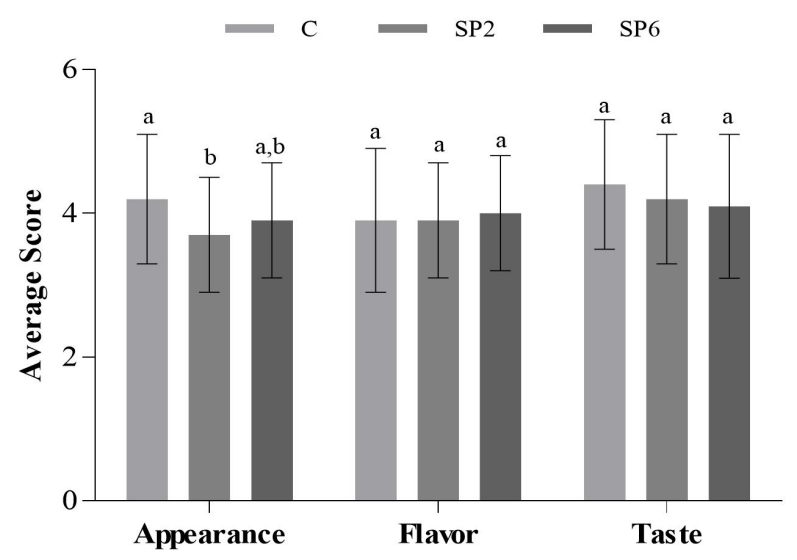

Figure 3. Sensory evaluation of snack bars control (C) and snack bars with $2 \%$ of Spirulina (SP2) and 6\% of Spirulina (SP6). Means \pm standard deviation $(n=50)$. Different letters mean significant differences between samples $(\mathrm{p}<0.05)$.

(2017) evaluated the sensorial characteristics of cookies added with 2 and $6 \%$ of the microalgae Spirulina and Chlorella. The authors revealed that the cookies enriched with 2\% Spirulina were the preferred by consumers concerning sensory parameters of taste and global appreciation.

In the present study, the snack bars received scores between (3) neither like nor dislike and (4) like for the flavor, without showing a significant difference $(p>0.05)$ between the samples. Regarding the taste, the mean was considered high for all samples of snack bars, since it remained between (4) like and (5) like a lot (Figure 3), without significant differences between the samples $(\mathrm{p}>0.05)$. These results indicate that although the hardness and moisture of the samples have shown significant differences $(\mathrm{p}<0.05)$ (Table 4$)$, the sensorial quality was not influenced. Thus, Spirulina may be considered relevant as an ingredient of snack bars intended for schoolchildren feeding.

\section{Conclusion}

We conclude that Spirulina can be used in the nutritional enrichment of snack bars. The addition of $2 \%$ and $6 \%$ of this microalga resulted in an increase of $11.7 \%$ and $29.9 \%$ in protein content, respectively, besides significantly affecting the color of the snack bars. The snack bars maintained their texture and color stable besides remaining microbiologically safe during the storage period evaluated (30 days).

Sensory evaluation showed that the snack bars enriched with $2 \%$ and $6 \%$ of Spirulina had the attributes appearance, flavor, and taste enjoyed by schoolchildren. Therefore, the use of Spirulina as an ingredient of snack bars designed for infant feeding is considered promising as an alternative to improve their nutritional health.

\section{Acknowledgements}

The authors thank the Ministry of Science, Technology, Innovations, and Communications (MCTIC) (Project 01200.005005/2014-49) for providing the funding for this research, to the Coordination for the Improvement of Higher Education Personnel (CAPES) for granting scholarships and to CEME-SUL/FURG (Electron Microscopy Center of Southern) due to the scanning electron microscopy.

\section{References}

Aigster, A., Duncan, S. E., Conforti, F. D., \& Barbeau, W. E. (2011). Physicochemical properties and sensory attributes of resistant starchsupplemented granola bars and cereals. Lebensmittel-Wissenschaft + Technologie, 44(10), 2159-2165. http://dx.doi.org/10.1016/j. lwt.2011.07.018.

Association of Official Analytical Chemists. (1995). Official methods of analysis of the association of analytical chemists international (16th ed.). Virgínia: AOAC International.

Barkallah, M., Dammak, M., Louati, I., Hentati, F., Hadrich, B., Mechichi, T., Ayadi, M. A., Fendri, I., Attia, H., \& Abdelkafi, S. (2017). Effect of Spirulina platensis fortification on physicochemical, textural, antioxidant and sensory properties of yogurt during fermentation and storage. Lebensmittel-Wissenschaft + Technologie, 84, 323-330. http://dx.doi.org/10.1016/j.lwt.2017.05.071.

Batista, A. P., Niccolai, A., Fradinho, P., Fragoso, S., Bursic, I., Rodolfi, L., Biondi, N., Tredici, M. R., Sousa, I., \& Raymundo, A. (2017). Microalgae biomass as an alternative ingredient in cookies: Sensory, physical and chemical properties, antioxidant activity and in vitro digestibility. Algal Research, 26, 161-171. http://dx.doi.org/10.1016/j. algal.2017.07.017.

Bialek, M., Rutkowska, J., \& Radomska, J. (2016). Nutritional value and consumer acceptance of new cereal bars offered to children. Polish Journal of Food and Nutrition Sciences, 66(3), 211-219. http://dx.doi. org/10.1515/pjfns-2015-0033.

Carvalho, L. F., Moreira, J. B., Oliveira, M. S., \& Costa, J. A. V. (2017). Novel food supplements formulated with Spirulina to meet athletes' needs. Brazilian Archives of Biology and Technology, 60, 1-11.

Food and Drug Administration. (2002a). GRAS Notification for Spirulina microalgae. Washington: FDA. Retrieved from https://www.accessdata. fda.gov/scripts/fdcc/index.cfm?set=GRASNotices\&id=101\&sor $\mathrm{t}=\mathrm{GRN}$ _No\&order=ASC\&startrow=1\&type=basic\&search $=265$

Food and Drug Administration. (2002b). Enumeration of Escherichia coli and the Coliform Bacteria. In Food and Drug Administration. Bacteriological analytical manual (chap. 4). Washington: FDA. Retrieved from http://www.fda.gov/Food/FoodScienceResearch/ LaboratoryMethods/ucm064948.htm

Food and Drug Administration. (2007). Salmonella. In Food and Drug Administration. Bacteriological analytical manual (chap. 5). Washington: FDA. Retrieved from http://www.fda.gov/Food/ FoodScienceResearch/LaboratoryMethods/ucm070149.htm

Food and Drug Administration. (2017). Requirements for specific standardized cereal flours and related products. Washington: FDA. Retrieved from https://www.accessdata.fda.gov/scripts/cdrh/cfdocs/ cfcfr/CFRSearch.cfm?CFRPart=137\&showFR=1

Fradique, M., Batista, A. P., Nunes, M. C., Gouveia, L., Bandarra, N. M., \& Raymundo, A. (2010). Incorporation of Chlorella vulgaris and Spirulina maxima biomass in pasta products. Part 1: preparation and evaluation. Journal of the Science of Food and Agriculture, 90(10), 1656-1664. http://dx.doi.org/10.1002/jsfa.3999. PMid:20564448.

Gutkoski, L. C., Bonamigo, J. M. A., Teixeira, D. M. F., \& Pedó, I. (2007). Desenvolvimento de barras de cereais à base de aveia com alto teor de fibra alimentar. Food Science and Technology, 27(2), 355-363. http://dx.doi.org/10.1590/S0101-20612007000200025. 
Henrikson, R. (2009). Earth food Spirulina (6th ed.) Maui: Ronore Enterprises Inc.

Hosseini, S. M., Khosravi-Darani, K., \& Mozafari, M. R. (2013). Nutritional and medical applications of Spirulina microalgae. Mini-Reviews in Medicinal Chemistry, 13(8), 1231-1237. http://dx.doi.org/10.2174/ 1389557511313080009. PMid:23544470.

Konica Minolta. (2007). Precise color communication: color control from perception to instrumentation (1st ed.). Japan: Konica Minolta, Inc.

Limbo, S., \& Piergiovanni, L. (2006). Shelf life of minimally processed potatoes: Part 1. Effects of high oxygen partial pressures in combination with ascorbic and citric acids on enzymatic browning. Postharvest Biology and Technology, 39(3), 254-264. http://dx.doi.org/10.1016/j. postharvbio.2005.10.016.

Lucas, B. F., Morais, M. G., Santos, T. D., \& Costa, J. A. V. (2017). Effect of Spirulina addition on the physicochemical and structural properties of extruded snacks. Food Science and Technology, 37(spe), 16-23. http://dx.doi.org/10.1590/1678-457x.06217.

Lucas, B. F., Morais, M. G., Santos, T. D., \& Costa, J. A. V. (2018). Spirulina for snack enrichment: Nutritional, physical and sensory evaluations. Lebensmittel-Wissenschaft + Technologie, 90, 270-276. http://dx.doi.org/10.1016/j.lwt.2017.12.032.

Mathlouthi, M. (2001). Water content, water activity, water structure and the stability of foodstuffs. Food Control, 12(7), 409-417. http:// dx.doi.org/10.1016/S0956-7135(01)00032-9.

Montgomery, D. C. (2009). Design and analisys of experiments (8th ed.). Arizona: John Wiley \& Sons, Inc.

Morais, M. G., Miranda, M. Z., \& Costa, J. A. V. (2006). Biscoitos de chocolate enriquecidos com Spirulina platensis: características físico-químicas, sensoriais e digestibilidade. Alimentos e Nutrição, 17(3), 323-328.

Morais, M. G., Reichert, C. C., Dalcanton, F., Durante, A. J., Marins, L. F., \& Costa, J. A. (2008). Isolation and characterization of a new Arthrospira strain. Zeitschrift fur Naturforschung. C, Journal of Biosciences, 63(1-2), 144-150. http://dx.doi.org/10.1515/znc-20081-226. PMid:18386504.

Müller, O., \& Krawinkel, M. (2005). Malnutrition and health in developing countries. Canadian Medical Association Journal, 173(3), 279-286. http://dx.doi.org/10.1503/cmaj.050342. PMid:16076825.

Núcleo de Estudos e Pesquisas em Alimentação. (2011). Tabela Brasileira de Composição de Alimentos - TACO. Campinas: NEPA. Retrieved from http://www.cfn.org.br/wp-content/uploads/2017/03/ taco_4_edicao_ampliada_e_revisada.pdf

Oyeyinka, S. A., Tijani, T. S., Oyeyinka, A. T., Arise, A. K., Balogun, M. A., Kolawole, F. L., Obalowu, M. A., \& Joseph, J. K. (2018). Value added snacks produced from Bambara groundnut (Vigna subterranea) paste or flour. Lebensmittel-Wissenschaft + Technologie, 88, 126-131. http://dx.doi.org/10.1016/j.lwt.2017.10.011.

Pinto, V. R. A., Freitas, T. B. O., Dantas, M. I. S., Della Lucia, S. M., Melo, L. F., Minim, V. P. R., \& Bressan, J. (2017). Influence of package and health-related claims on perception and sensory acceptability of snack bars. Food Research International, 101, 103-113. http://dx.doi. org/10.1016/j.foodres.2017.08.062. PMid:28941673.
Potter, R., Stojceska, V., \& Plunkett, A. (2013). The use of fruit powders in extruded snacks suitable for Children's diets. LebensmittelWissenschaft + Technologie, 51(2), 537-544. http://dx.doi.org/10.1016/j. lwt.2012.11.015.

Prazeres, I. C., Domingues, A. F. N., Campos, A. P. R., \& Carvalho, A. V. (2017). Elaboration and characterization of snack bars made with ingredients from the Amazon. Acta Amazonica, 47(2), 103-110. http://dx.doi.org/10.1590/1809-4392201602203.

Ramírez-Jiménez, A. K., Gaytán-Martínez, M., Morales-Sánchez, E., \& Loarca-Pina, G. (2018). Functional properties and sensory value of snack bars added with common bean flour as a source of bioactive compounds. Lebensmittel-Wissenschaft + Technologie, 89, 674-680. http://dx.doi.org/10.1016/j.lwt.2017.11.043.

Rodríguez De Marco, E., Steffolani, M. E., Martínez, C. S., \& León, A. E. (2014). Effects of Spirulina biomass on the technological and nutritional quality of bread wheat pasta. Lebensmittel-Wissenschaft + Technologie, 58(1), 102-108. http://dx.doi.org/10.1016/j.lwt.2014.02.054.

Ryland, D., Vaisey-Genser, M., Arntfield, S. D., \& Malcolmson, L. J. (2010). Development of a nutritious acceptable snack bar using micronized flaked lentils. Food Research International, 43(2), 642649. http://dx.doi.org/10.1016/j.foodres.2009.07.032.

Santos, T. D., Freitas, B. C. B., Moreira, J. B., Zanfonato, K., \& Costa, J. A. V. (2016). Development of powdered food with the addition of Spirulina for food supplementation of the elderly population. Innovative Food Science \& Emerging Technologies, 37, 216-220. http://dx.doi.org/10.1016/j.ifset.2016.07.016.

Silva Figueira, F., Moraes Crizel, T., Rubira Silva, C., \& las Mercedes Salas-Mellado, M. (2011). Pão sem glúten enriquecido com a microalga Spirulina platensis. Brazilian Journal of Food Technology, 14(4), 308-316. http://dx.doi.org/10.4260/BJFT2011140400037.

Srebernich, S. M., Gonçalves, G. M. S., Ormenese, R. C. S. C., \& Ruffi, C. R. G. (2016). Physico-chemical, sensory and nutritional characteristics of cereal bars with addition of acacia gum, inulin and sorbitol. Food Science and Technology, 36(3), 555-562. http:// dx.doi.org/10.1590/1678-457X.05416.

Sun-Waterhouse, D., Teoh, A., Massarotto, C., Wibisono, R., \& Wadhwa, S. (2010). Comparative analysis of fruit-based functional snack bars. Food Chemistry, 119(4), 1369-1379. http://dx.doi.org/10.1016/j. foodchem.2009.09.016.

United Nations Children's Fund. (2018). Micronutrients. New York: UNICEF. Retrieved from https://www.unicef.org/nutrition/ index_iodine.html

World Health Organization. (2014). Countries vow to combat malnutrition through firm policies and actions. Geneva: WHO. Retrieved from http:// www.who.int/mediacentre/news/releases/2014/icn2-nutrition/en/

You, Y., Li, N., Han, X., Guo, J., Zhao, Y., Liu, G., Huang, W., \& Zhan, J. (2018). Influence of different sterilization treatments on the color and anthocyanin contents of mulberry juice during refrigerated storage. Innovative Food Science \& Emerging Technologies, 48, 1-10. http://dx.doi.org/10.1016/j.ifset.2018.05.007. 